\section{How do Consumption Values Influence Online Purchase Intention among School Leavers in Malaysia?}

\section{T. Ramayah'}

${ }^{1}$ Universiti Sains Malaysia, School of Management, Minden, Penang, Malaysia

\author{
Syed Abidur Rahman ${ }^{2}$ \\ ${ }^{2}$ College of Economics \& Political Science, Sultan \\ Qaboos University, Muscat, Oman \\ Ng Ching Ling ${ }^{3}$ \\ ${ }^{3}$ School of Management, Universiti Sains Malaysia, Minden, \\ Penang, Malaysia
}

\begin{abstract}
Purpose - The purpose of this study is to reveal the significant consumption values of consumers that drive them towards online purchasing. The study conceptualised and analysed a consumption value model as a predictor for intention to purchase online in the context of Malaysian school leavers familiar with the internet.
\end{abstract}

Design/methodology/approach - In order to achieve its aim, this study carried out empirical research using a structured questionnaire sent to the potential respondents. In addition, the data were analysed using the structural equation modelling technique.

Findings - The result of the study indicates that functional and emotional values have a strong relationship and predict online purchasing intention. However, social, epistemic, and conditional values do not predict intentions to purchase online.

Originality/value - The result will increase the understanding of owners and managers of e-commerce businesses and help them to formulate their business strategies in order to retain users and attract new ones. Furthermore, the study will also enable e-commerce stakeholders to offer products/services to consumers in order to enhance e-commerce activities.

Keywords - Consumption values, Online purchase intention, Shopping, Internet, Malaysian.

638

Received on

04/03/2016

Approved on

$06 / 28 / 2018$

\section{Responsible editor:}

Prof. Dr. Guilherme Shiraishi

\section{Evaluation process:}

Double Blind Review

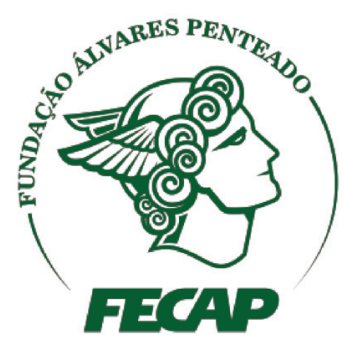

Review of Business Management 


\section{Introduction}

Shopping is a social experience and social networking enables consumers to interact (Pookulangara \& Koesler, 2011). Today's consumers increasingly use technology as an effective tool for shopping on online platforms. The emergence of online shopping triggered by information technology (IT) has been revolutionary in the context of a global market setting (Sin, Nor, \& Al-Agaga, 2012). In fact, online shopping has prompted the growth of internet-based commerce around the globe as it is convenient and appropriate for consumers (Javed, Nazam, Ahmad, Nadeem, \& Qadeer, 2015). Additionally, the acceptance of Web 2.0 has opened the door to building a new world of collaboration and communication. According to Gopi and Ramayah (2007), the internet emerged as a result of the convergence between telecommunication and computers, which has transfigured business processes and operations. Scholars have credited internet retailing as one of the rapid emergent distribution channels for trade (Ramayah \& Ignatius, 2005). In this regard, it is relevant to mention that internet retailing has grown exponentially around the globe (Verma, Sharma, \& Sheth, 2015) and was expected to reach USD 1.7 trillion by the end of 2015 (San Lim, Omar, \& Thurasamy, 2015). Borderless geography in cyberspace has created enormous opportunities for almost everyone around the globe and Malaysia as a developing country is no exception to this (Sin et al., 2012). In Malaysia, scholars have observed a major directional shift from purchasing in physical stores to online purchasing in the retailing industry (Ling, Daud, Piew, Keoy, \& Hassan, 2011). Despite the numbers of online purchases increasing across countries, scholars have put forward that the growth of online purchasing in Malaysia is still slow compared to the global trend (Samuel, Balaji, \& Kok Wei, 2015; San Lim et al., 2015). It is important to mention that online purchasing is carried out virtually, therefore placing more importance on consumers' purchase judgments
(Park, Lee, \& Han, 2007). In the context of purchase judgments, pundits have pointed to the significance of consumer value, which is also labelled as a global phenomenon (Sweeney \& Soutar, 2001). Therefore, business managers in online shopping must understand consumer value, which is represented by consumption value (Woodruff, 1997), as theorised by Sheth, Newman, and Gross (1991). Conceptualisation of the consumption values of online purchasers will enable an understanding of online purchasing intention among internet users in Malaysia. Research shows that around fifty-eight percent of internet users consider going online to be a frustrating and overwhelming activity (Dai, Forsythe, \& Kwon, 2014). In this context,

several studies have been conducted to frame the online purchasing intention of the Malaysian populace. One such study involved identifying the factors that influence intentions to use internet stock trading platforms among investors in Malaysia (Ramayah, Rouibah, Gopi, \& Rangel, 2009). Because a comparatively slow progression of online purchasing has been detected in Malaysia, it is worthwhile to carry out research on intention to purchase online in this context by bringing in the consumption value model. Therefore, the objective of this study is to reveal the possible relationship between the dimensions of the consumption value model and intention to purchase online. It is anticipated that statistically identifying the probable consumption values underlying the intention to purchase online will add scholastic merit to the field of consumer behaviour and e-commerce research. Specifically, this study will further deepen the knowledge on values that influence consumers' intentions in online shopping. In order to accomplish the objective, this paper will illustrate the theoretical background and conduct a literature review in the next section. Subsequently, this study proposes a research framework, which will be followed by the research methodology and findings. Finally, this paper ends with a discussion on the statistical findings. 


\section{Theoretical Background and Literature Review}

Purchasing intention over the counter (OTC) in shopping centres and, recently, via online shopping, has become an interesting area for worthwhile research. Even though extensive research has been carried out to reveal the predictors and outcomes of intention to purchase, it is still considered to be a domain for further studies as it can be driven by a diverse range of psychological, philosophical, social, and economic factors. Intention has been defined by scholars as a perception of an individual leading to the performance of a specific behaviour or the subjective probability of the relationship between a person and action (Ajzen \& Fishbein, 1977; Fishbein \& Ajzen, 1975). In the theory of reasoned action (TRA), the scholars concerned revealed the predictive relationship of attitude and subjective norms with intention (Fishbein $\&$ Ajzen, 1975). However, afterwards in an attempt to extend the TRA, the antecedent of intention was found to be the attitude towards the behaviour, the subjective norm, and the degree of perceived behavioural control, which is known as the theory of planned behaviour (TPB) (Ajzen \& Driver, 1992). In another theoretical perspective, which is the technology acceptance model (TAM), Davis (1989) validated perceived usefulness and perceived ease of use as antecedents of intention. Meanwhile, Chau and $\mathrm{Hu}$ (2001) proposed a decomposed theory of planned behaviour (TPB), where TAM and TPB were integrated and perceived usefulness, perceived ease of use, attitude towards behaviour, subjective norms, and perceived behavioural control were modelled as the antecedents of intention. However, in the area of consumer research, one of the significant theories is consumption value theory, which depicts the value reasons for a certain consumer's choice.

\section{The Consumption Value Model}

Products and services are the core element in any business transaction (Johnson, Christensen,
\& Kagermann, 2008). Nowadays, the majority of business transactions are carried out through the internet, where online purchasing plays a vital role. There are many factors that influence consumers' intentions when making the decision to purchase a product or service. For example, in the domain of online purchasing, consumer value accounts for a significant part of academic research. (Childers, Carr, Peck, and Carson (2002); Kim (2002); Overby and Lee (2006)). Because retail consumers are value driven, it is important for the stakeholders concerned to focus their attentions on consumer value related issues (Sweeney \& Soutar, 2001). There have been various attempts to define consumer value, with an assortment of thoughts from a number of perspectives in the customer oriented management domain, showing great interest in value in various research areas. For instance, Schechter (1984) defined value as all aspects, both qualitative and quantitative, as well as subjective and objective, that make up the whole shopping experience. Zeithaml (1988) defined value as consumers' overall assessment of the utility of a product based on perceptions of what is received and what is given, even though what is given and what is received varies between consumers. Later on, the notion of value was adjusted slightly with the proposition by Woodruff (1997), where it was defined as customers' perceived inclination for and assessment of those product features, quality performances, and results arising from their goals and intentions. Value is commonly seen as a key tool for understanding human behaviours and doing business (Sheth et al., 1991; Sweeney \& Soutar, 2001; Woodruff, 1997). However, 'why consumers buy' is one of the fundamental questions that are asked in consumer behaviour, as well as marketing and economics literature. In this regard, according to Turel, Serenko, and Bontis (2010), value components, such as emotional value, value for money, and quality, are used as the basis upon which consumers develop their choice behaviour and are captured in the consumption value perception. Sheth et al. (1991) amalgamated 
a theoretical framework drawn from economics, psychology,

sociology, marketing, and consumer behaviour, which postulates that five consumption values influence consumers' choice behaviour. This perspective from Sheth et al. (1991) extends the concept of value illustrated by Bolton and Drew (1991) and Cravens, Holland, Lamb, and Moncrief (1988), as it enables values beyond monetary aspects to be considered. According to consumption value theory, consumer choice is a function of multiple consumption values (Turel et al., 2010), which leads to an understanding of actual consumer behaviour in a market choice situation (Sheth et al., 1991). In a similar manner, Engström, Styvén, Wallström, and Salehi-Sangari (2015) illustrated that values make varying contributions to choices among consumers. For some time, one of the key influential factors in consumer choice was considered to be functional value (Sweeney $\&$ Soutar, 2001). However, Sheth et al. (1991) found that other value dimensions, such as social value, emotional values, conditional value, and epistemic value were also influential in some situations. According to Sheth et al. (1991) functional value is the perceived utility that is derived from a product's physical, utilitarian, or functional attributes. In the words of Long and Schiffman (2000), functional value is based on the intrinsic value of the product or service rather than on any extrinsic value. Social value is derived from an alternative association with an identified demographic, socioeconomic, cultural, or ethnic group (Sheth et al., 1991). Consumers who are driven by social value are expected to choose in accordance with groups to which they belong, identify with, or aspire to belong (Long \& Schiffman, 2000). As illustrated by Sheth et al. (1991), emotional value is obtained from the aptitude of an alternative to stimulate an emotional or affective state, while epistemic value is developed by an alternative as the outcome of its ability to arouse interest, deliver novelty, and/ or satisfy an aspiration for knowledge. According to Long and Schiffman (2000), epistemic utility is often derived from stimuli that are novel and somewhat equivocal. Last but not the least, conditional value is considered as stemming from the particular condition or context of the purchase decision (Sheth et al., 1991). In a previous study conducted in Malaysia, consumption values were considered as predictors for the desire among consumers for green products (Mohd Suki \& Mohd Suki, 2015). Other scholars asserted that consumption values are the motivational drivers for suburban choices in New Zealand (Lee, Levy, Yap, \& Sheau, 2015). Researchers have also noted that most consumption values are independent, and changes in one dimension may not necessarily result in changes in others. Therefore, the effect of multiple value dimensions should be taken into consideration simultaneously as predictors of behaviour (Turel et al., 2010) such as purchase intention.

\section{Online Purchase Intention}

Purchasing online has certainly become one of the most effective, necessary, and popular activities on the cybernet, or internet (Flanagin, Metzger, Pure, Markov, \& Hartsell, 2014; Moon, Chadee, \& Tikoo, 2008). The ease of access to information online has led to a proliferation in the online shopping phenomenon. Most people now conduct their investments, banking, and shopping via the internet (Ling et al., 2011). Pavlou (2003) defined online purchase intention as a situation where a consumer is willing and intends to make online transactions. Chu and $\mathrm{Lu}$ (2007) pointed out that the extent of a consumer's inclination towards buying online is the online purchase intention. Previously, Zwass (1998) defined online purchase intention as a consumer's intention to create an online association and engage in transactions with a web vendor. While defining online transaction, Pavlou (2003) identified three sequential steps that together make up an online transaction. These are: information retrieval, information transfer, and product purchase. However, San Martín and Herrero (2012) suggested that online purchase intention can also 
be considered as a dependable indicator of the degree for recognition of new technologies by users. Previous studies have carried out extensive research to explore the antecedents or predictors of online purchase intention. In the field information technology, one of the most popular models is the Unified Theory of Acceptance and Use of Technology (UTAUT), which denotes performance expectancy, effort expectancy, and social influence as the predictors for intention (Venkatesh, Morris, Davis, \& Davis, 2003). In a study conducted by Gopi and Ramayah (2007), attitude, social pressure, and perceived behavioural control were found to predict intention regarding internet stock trading. However, trust has been considered as one of the most validated antecedents of intention to purchase online in several studies (Everard \& Galletta, 2005; Gefen, Karahanna, \& Straub, 2003; Van der Heijden, Verhagen, \& Creemers, 2003). Furthermore, it was found that product category (Dai et al., 2014), perceived enjoyment (Ramayah \& Ignatius, 2005), and users' innovativeness (San Martín \& Herrero, 2012) play an influential role in explaining online purchase intentions. In another study, Javed et al. (2015) concluded that efforts by an online store to reduce particular risks will primarily enhance consumer trust, and eventually lead to intensifying consumers' online purchase intentions. The discussion above gives a brief overview of the previous literature that has revealed predictors of online purchase intention. However, along with these predictors, there are other factors that presumably play an instrumental role in shaping online purchase intention, such as consumption values.

\section{Hypotheses Development}

According to Ok-Kim and Jin (2001), perceived functional utility can be considered to reflect shopping efficiency, which is the level of convenience and speed to be able to access a desired offering. In terms of convenience and speed, nowadays, online shopping or purchasing is the most appropriate method to accept and exchange offers. Scholars have noted that internet retailing is more convenient (Hsin Chang \& Wang, 2011) and time efficient (Lee, Eze, \& Ndubisi, 2011) for obtaining a desired product or service compared to traditional ways of shopping. As online purchasing is efficient and effective, there is enhanced value in terms of functional capabilities compared to traditional shopping (Pavlou, 2003). This presence of functional value in using the internet would possibly increase consumers' intentions to purchase online in greater amounts. In this regard, the first hypothesis of this study is:

H1: The perceived functional value of the internet is positively associated with customer intention to purchase online.

According to Sheth et al. (1991), social value is a perceived utility acquired from an alternative association with one or more specific social groups. The social image of a product or service presented in a customer's mind can influence that customer's choice, especially for purchases that involve a superior image. Nowadays, the internet is considered as a modern platform for performing any activity. Although the internet reduces socialisation, there are still some human interactions involved (Wu, 2013). There is even an argument that the internet medium is also capable of delivering social value to its users. With technology constantly improving, the internet serves as a wide communication channel for social interaction as users are able to share experiences and information via the likes of online forums, online communities, and interest group websites (Laroche, Habibi, Richard, \& Sankaranarayanan, 2012). Therefore, the literature review and discussion above leads to the following hypothesis:

\section{H2: The perceived social value of the internet is positively associated with customer intention to purchase online.}

Sheth et al. (1991) portrayed emotional value as the perceived utility acquired from an 
alternative's capacity to arouse positive emotions and feelings or affective states in a constructive manner. This perhaps goes beyond any economic value or monetary worth of feelings when customers positively experience products and services. Emotional value represents the emotional part of willingness to accept once we exclude any rational financial behaviour by the owner (Zellweger \& Astrachan, 2008), which in turn influences a consumer's purchase decision (Mohd Suki \& Mohd Suki, 2015). According to Kacen, Hess, and Chiang (2013), consumers' attitudes and behaviour toward internet shopping undergo a positive change when there is interactivity that creates a link between consumers' preferences, values, and self-image on the one hand, and consumers' attitudes on the other. Emotional value can be related to the development of positive emotions, such as happiness, interest, and pleasant surprise (Westbrook \& Oliver, 1991). In addition, emotional value is consistent with optimal stimulation theory, where individuals are likely to select positive situations (Moore \& Harris, 1996). In a retailing environment, a positive emotional experience for an audience/target market creates enjoyment and entertainment (Ducoffe, 1996), which leads to value creation that is hedonistic in nature (Hoffman \& Novak, 1996). Looking at enjoyment and entertainment together, Westbrook and Oliver (1991) suggested that it would eventually motivate pleasurable behaviour in the context of purchase intention. In this study, the intention to purchase online is associated with the development of a range of emotions. With this, it is posited that:

H3: The perceived emotional value of the internet is positively associated with customer intention to purchase online.

Epistemic utility often results from incitements that are novel and somewhat ambiguous (Long \& Schiffman, 2000). With the variety of products available in the market nowadays, consumers have the purchasing power to decide which brand's product they will purchase. Due to this luxury, customers may choose another new product because they are bored with the previous brand or simply to satisfy a search for variety. Consumer loyalty is hard to maintain for this reason. Therefore, epistemic value is capable of influencing both purchase intention and switching behaviour in the context of online shopping. Epistemic value explains that the online shopping intention is due to consumers' curiosity and the desire for knowledge. With an interactive communication channel available online and a huge market to tap into, online websites are able to take up this opportunity to create a new and regularly updated shopping environment in order to cater to potential consumers' curiosity. There is a parallel connection between consumers' pleasures and perceived satisfaction, which then leads to an increasing effect on online shopping intention (Van Birgelen, Jong, \& Ruyter, 2006). Scholars have alluded to the notion that the inherently encyclopaedic and transparent nature of the internet makes it a suitable medium for an acquisition of epistemic value (Hanson $\&$ Kalyanam, 2007). In view of this, the next hypothesis proposed is:

H4: The perceived epistemic value of the internet is positively associated with customer intention to purchase online.

Conditional value derives from a specific situation or context of a purchasing decision (Long \& Schiffman, 2000). The measurement of conditional value involves a set of choice contingencies. Conditional value refers to situational contingencies contributing to temporary functional and social utility (Pope, 1998). This situation may have an influence over a consumer's decision making process. Income, a stock-out situation, fashion, etc. could manipulate a consumer's purchasing decisionmaking process. Conditional value has been influenced by several lines of inquiry. These have recognised the importance of the learning 
that takes place as a result of experiencing a given situation (Pihlström \& Brush, 2008). Any consumer purchase intention is greatly affected by the situation the consumer is in because different situations create a different impact on his/her final decision. Therefore, retailers should create a favourable situation that will increase the consumer's intention to purchase online.

H5: The perceived conditional value of the internet is positively associated with customer intention to use the internet as a retailing platform.

\section{Research Method}

The respondents of this study are individuals who have a different level of exposure in terms of the internet and the online shopping experience in Malaysia. The distribution of the questionnaires is restricted to individuals who are school leavers and familiar with the internet. About 200 sets of questionnaires were sent via email and only 139 replies were received. Among the 139 respondents, only 127 questionnaires were filled out completely. All constructs and items were adapted from the existing literature and modified to suit the purposes of this study. All major items are based on a seven-point Likert scale ranging from strongly disagree (1) to strongly agree (7). Functional value (4 items), social value ( 5 items), emotional value ( 4 items), conditional value (6 items), epistemic value (4 items), and consumer intention to purchase (3 items) are adapted from Long and Schiffman
(2000) and Lee, Kim, Lee, and Kim (2002). The data were analysed using the partial least squares (PLS) approach. The results were presented in three steps. Firstly, a Harman single factor test was performed to test the existence of common method bias in the study. Secondly, the results of the measurement model were assessed and discussed. Thirdly, the results for the hypotheses were assessed by examining the structural model.

\section{Findings}

In this study, first, the existence of common method bias was examined using Harman's single factor test, as suggested by Podsakoff, MacKenzie, Lee, and Podsakoff (2003) and Podsakoff and Organ (1986). The result shows that the first factor captured $33 \%$ of the variance in the data, which is less than the $50 \%$ threshold level of total variance explained. The quality of the measurement model was assessed by examining convergent validity, which includes factor loading, average variance extracted (AVE), composite reliability (CR), and discriminant validity, as suggested by Hair, Ringle, and Sarstedt (2011) as a rule of thumb for model evaluation. While checking factor loading and cross loading, 2 items (Condv 5 and Condv 6) were dropped. The results show that indicator loadings for all items exceeded the recommended value of 0.7, AVE was between 0.598 and 0.810 , which is above the recommended value of 0.5 , and CR ranged from 0.868 to 0.944 , which exceeds the recommended value of 0.7 (Hair, Black, Babin, \& Anderson, 2009). The results are shown in Table 1. 
Table 1

Results of Measurement Model

\begin{tabular}{|c|c|c|c|c|}
\hline Variable & Item & Loadings & AVE $^{1}$ & $\mathbf{C R}^{2}$ \\
\hline \multirow[t]{4}{*}{ Functional value } & funcv1 & 0.860 & 0.761 & 0.927 \\
\hline & funcv2 & 0.907 & & \\
\hline & funcv3 & 0.891 & & \\
\hline & funcr 4 & 0.830 & & \\
\hline \multirow[t]{5}{*}{ Social value } & socv1 & 0.607 & 0.598 & 0.880 \\
\hline & socv2 & 0.784 & & \\
\hline & socv3 & 0.803 & & \\
\hline & socv 4 & 0.809 & & \\
\hline & socv 5 & 0.840 & & \\
\hline \multirow[t]{4}{*}{ Emotional value } & emov1 & 0.831 & 0.810 & 0.944 \\
\hline & emov2 & 0.928 & & \\
\hline & emov3 & 0.904 & & \\
\hline & emov4 & 0.933 & & \\
\hline \multirow[t]{4}{*}{ Epistemic value } & epi1 & 0.836 & 0.689 & 0.898 \\
\hline & epi2 & 0.848 & & \\
\hline & epi3 & 0.885 & & \\
\hline & epi4 & 0.745 & & \\
\hline \multirow[t]{4}{*}{ Conditional value } & condv1 & 0.892 & 0.628 & 0.868 \\
\hline & condv2 & 0.926 & & \\
\hline & condv3 & 0.601 & & \\
\hline & condv4 & 0.704 & & \\
\hline \multirow[t]{3}{*}{ Intention to Purchase Online } & int 1 & 0.916 & 0.829 & 0.936 \\
\hline & int 2 & 0.920 & & \\
\hline & int3 & 0.895 & & \\
\hline
\end{tabular}

Note. ${ }^{1}$ Average Variance Extracted (AVE) $=$ (summation of the square of the factor loadings) $/\{($ summation of the square of the factor loadings) + (summation of the error variances) $\}$

${ }^{2}$ Composite Reliability $(\mathbf{C R})=$ (square of the summation of the factor loadings)/\{(square of the summation of the factor loadings + (square of the summation of the error variances) $\}$

Following this, the discriminant validity was tested for the measurement model. It was checked by comparing the correlations between variables and the square root of the average variance extracted for those particular variables (Fornell \& Larcker, 1981; Rahman, Taghizadeh, Ramayah, \& Ahmad, 2015)\&. As shown in Table
2 , the square root of the average variance extracted was higher than the correlation values in the row and the column, signifying adequate discriminant validity. Therefore, satisfactory convergent validity and discriminant validity of the measurement model was confirmed and so we proceeded to assess the structural model. 
Table 2

Discriminant Analysis for the Measurement Model

\begin{tabular}{llccccc}
\hline & $\mathbf{1}$ & $\mathbf{2}$ & $\mathbf{3}$ & $\mathbf{4}$ & $\mathbf{5}$ & $\mathbf{6}$ \\
\hline 1 & Conditional value & 0.792 & & & & \\
3 & Emotional value & 0.036 & $\mathbf{0 . 9 0 0}$ & & & \\
4 & Epistemic value & 0.042 & 0.391 & $\mathbf{0 . 8 3 0}$ & & \\
5 & Functional value & 0.130 & 0.663 & 0.348 & $\mathbf{0 . 8 7 2}$ & \\
6 & Intention to Purchase Online & 0.138 & 0.666 & 0.341 & 0.777 & $\mathbf{0 . 9 1 0}$ \\
\hline
\end{tabular}

Note. Diagonals represent the square root of the average variance extracted, while the other entries represent the squared correlations

The structural model signifies the association between the latent variables that were hypothesised in the research model (Duarte \& Raposo, 2010; Rahman \& Das, 2005). Table 3 and Figure 1 show the result of the structural model tested in this study. The $\mathrm{R}^{2}$ for intention to purchase online is 0.648 , which indicates that $64.8 \%$ of intention to purchase online is explained by the functional values and emotional values among Malaysian school leavers who are familiar with internet activities.

Table 3

Summary of the Structural Model

\begin{tabular}{llllll}
\hline Hs & Relationship & Std. Beta & SE & t-value & Decision \\
\hline $\mathbf{1}$ & Functional value-> Intention to Purchase Online & 0.582 & .066 & $8.827^{* *}$ & $\mathrm{~S}$ \\
$\mathbf{2}$ & Social value-> Intention to Purchase Online & 0.008 & .072 & 0.108 & $\mathrm{NS}$ \\
$\mathbf{3}$ & Emotional value-> Intention to Purchase Online & 0.259 & .083 & $3.113^{* *}$ & $\mathrm{~S}$ \\
$\mathbf{4}$ & Epistemic value-> Intention to Purchase Online & 0.036 & .058 & 0.628 & $\mathrm{NS}$ \\
$\mathbf{5}$ & Conditional value-> Intention to Purchase Online & 0.056 & .070 & 0.797 & $\mathrm{NS}$ \\
\hline
\end{tabular}

Note. ${ }^{* *} \mathrm{p} £ 0.01, \mathrm{~S}=$ supported, NS=not supported

The results show that functional value has a significant relationship with intention to purchase online $(\beta=0.582, \mathrm{p}<0.01)$. Similarly, emotional value has a significant relationship with intention to purchase online $(\beta=0.259$, $\mathrm{p}<0.01)$. Contrastingly, social value, epistemic value, and conditional value were not found to have a significant relationship with intention to purchase online. Therefore, hypotheses $\mathrm{H} 1$ and $\mathrm{H} 3$ were supported, but $\mathrm{H} 2, \mathrm{H} 4$, and $\mathrm{H} 5$ were not supported. 


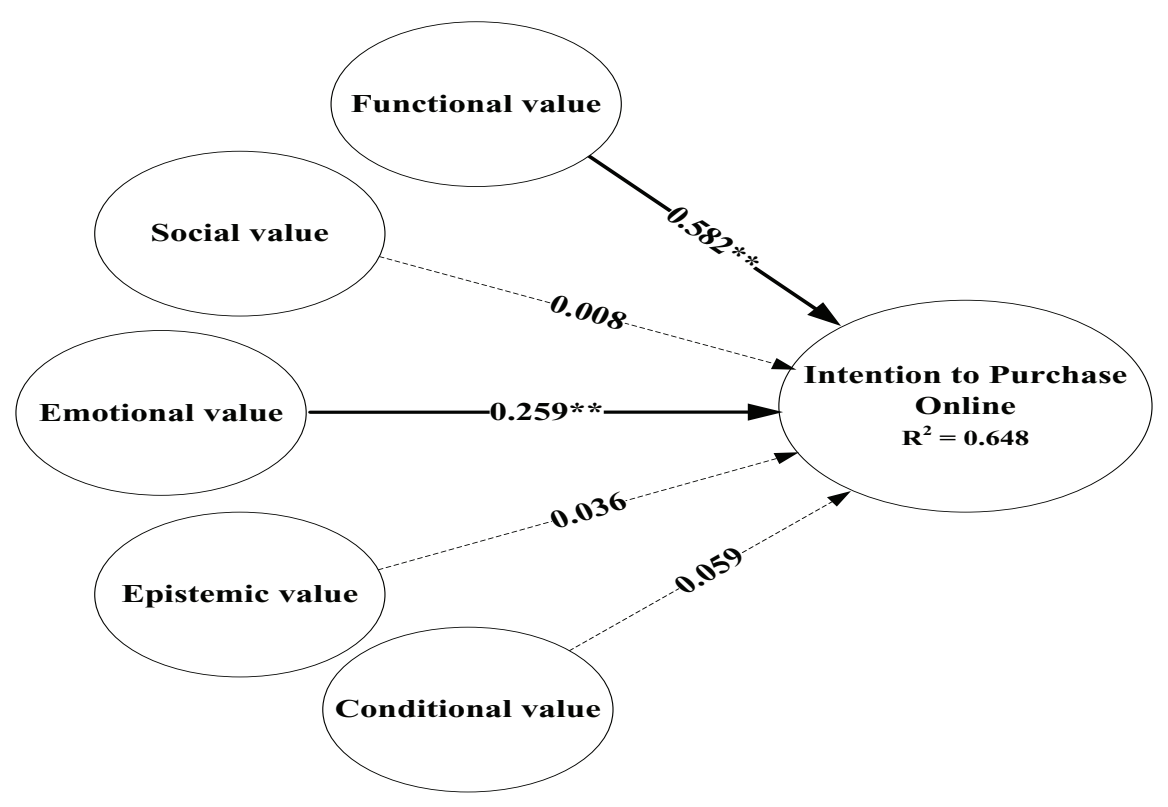

Figure 1. Structural model ${ }^{* *} \mathrm{p} £ 0.01$

\section{Discussion}

The reason underpinning this study is the relatively low intention of online purchasing in Malaysia compared to other countries. Therefore, this research was carried out to further understand and reveal the importance of consumption values in intention to purchase online among consumers using the internet as a retailing platform. Many earlier studies have explored and validated several predictors for online purchase intention, a few of which are: shopping orientation (Brown, Pope, $\&$ Voges, 2003), perceived value and trust (Bonsón Ponte, Carvajal-Trujillo, \& Escobar-Rodríguez, 2015), and attitude and perceived behavioural control (Amaro \& Duarte, 2015). Furthermore, previous studies have identified perceived value as a steadfast predictor for purchasing intention (Hellier, Geursen, Carr, \& Rickard, 2003; Sweeney \& Soutar, 2001). Specifically, Hur, Yoo, and Chung (2012) revealed that functional value, epistemic value, and emotional value drive purchase intention among South Korean urban consumers. Lee et al. (2015) found that place identity, which drives environmental attitudes and sustainable consumption behaviour, was significantly influenced by functional, social, emotional, epistemic, and conditional value. A study conducted in Malaysia among green product consumers revealed that social and epistemic values drive environmental concerns (Mohd Suki \& Mohd Suki, 2015). Moreover, the statistical analysis of the current study indicates that, along with functional value, hedonic value (i.e. emotional value) plays an instrumental role in online purchase intention amongst people who are school leavers, but currently using the internet. In a previous study, it was suggested that marketers are likely to be efficacious where products/services connect with customers' longterm value orientation (Alden, He, \& Chen, 2010).

In this study, functional value has the strongest positive relationship with customer intention to use the internet as a retailing platform. This aligns with the findings by Hur et al. (2012) and Engström et al. (2015), but contradicts the study by Mohd Suki and Mohd Suki (2015). Functional value stems from a perceived usefulness of the entity in the choice situation (Pope, 1998). It should be mentioned that the convenience and efficiency provided by internet shopping influence factors of consumers' 
desires to purchase a product or service online. Specifically, price and quality of the service and products determine online purchasing. When price and quality are aligned, consumers tend to purchase online. The values that were based on product/service functionalities determine the purchasing intention of this cohort of Malaysian consumers. This is perhaps consistent with the current trend of purchasing behaviour. The products/services that are offered in online portals must encompass value for money together with consistent performance. In relation to this, scholars have asserted that values serve to guide attitude and judgment regarding a specific objective (Long \& Schiffman, 2000)

Emotional value as suggested in the hypothesis plays an important role in influencing customer intention to use the internet as a retailing platform. The study by Lee, Lee, and Choi (2010) confirms that emotion serves as a bridge between need and behaviour, as the result revealed that emotional value has a positive association with behavioural intention. In the same vein, this study indicates that emotional value influences the inclination of consumers to purchase products online. According to the findings revealed by Sweeney and Soutar (2001), emotional value is the strongest predictor of purchasing behaviour in a physical environment. Scholars have argued that emotional value demonstrates various affective states or feelings related with consumption. Specifically, emotional value refers to the mental state of enjoyment and pleasure (Lee et al., 2010). The value that is generated through the enjoyment and satisfaction derived from using a particular product/service encourages consumers to purchase online. Perhaps when a consumer feels a state of relaxation coupled with a feeling of pleasure, this drives him or her purchase online.

However, other values, such as social, epistemic, and conditional value did not play a significant role in online purchase intention, as was expected in this study. While Mohd Suki and Mohd Suki (2015) found social value to influence environmental concern among Malaysian green product consumers, the result of this study suggests that social value does not have any impact on online purchase intention, which is in line with Hur et al. (2012). Another study by Turel et al. (2010) indicated that social value does not influence the overall value of a hedonic digital artefact. The reason is probably that social values create an impression of acceptance by others in society. However, it is a fact that this kind of value does not encourage Malaysian consumers to purchase online. Perhaps this is due to the fact that social acceptance of using a product/service does not a matter when purchasing online in Malaysian culture. When consumers purchase a product/service online, it is not an important issue for Malaysian consumers what other people think. Online purchasing is carried out mainly as a result of the intrinsic values of consumers themselves rather than any external factors.

The result of this study contradicts what Hur et al. (2012) found in their research. Epistemic value denotes the benefits resulting from an offering's ability to stimulate curiosity, provide uniqueness, or fulfil a desire for knowledge (Pope, 1998). A previous study supports the idea that epistemic value influences the environmental concerns of green product consumers (Mohd Suki \& Mohd Suki, 2015). However, in the context of this study, such curiosity, novelty, and desire for knowledge do not influence the intention to purchase online in Malaysia. Online shopping involves a platform where consumers are more concerned about the type and quality of a product/service and the reliability of their online transactions. Therefore, the desire to accumulate knowledge perhaps becomes trivial when purchasing online. Malaysian consumers are perceived to be trend followers, which means lesser importance is given to epistemic values.

Conditional value refers to a situational factor that either encourages consumers to purchase or not (Turel et al., 2010). A previous study reported that conditional value does not influence the environmental concerns of green product consumers. In the context of this present 
study, conditional value also does not play an instrumental role in online purchase intention, which is similar to in the study by Hur et al. (2012). This may be due to the fact that not every situation, whether favourable or unfavourable, will affect intention to purchase online, because conditional value depends on the specific situation of the decision maker, which also varies in different contexts (Smith \& Colgate, 2007). As consumers are well aware of the purchasing process, it is less important to consider every situation. Malaysian internet consumers are more inclined to consider other values when purchasing online, such as emotional and functional ones. As long as the functional and emotional factors are related, this cohort of Malaysian consumers will be inclined to purchase online.

\section{Implications and Suggestions for Future Research}

The implications of this research should be examined from a management perspective to execute the best strategies to increase online consumer purchasing. Purchasing online has become a significant part of life today. Due to the wide-range availability of the internet and its profound usage, consumers are inclined towards online purchasing. Nevertheless, research has suggested that in developing countries it is not as popular as in developed countries. The current study revealed that some of the dimensions of consumption values significantly influence Malaysian consumers in their intentions to purchase online. Business and managers could use these findings as a tool to attract potential consumers. When launching an online purchasing platform, managers of online businesses could address functional values in their business strategies. From this standpoint, managers should balance product quality with the price offered, which would perhaps encourage consumers to purchase online. If a consumer can obtain the same quality of products online compared to those sold in a shop, with the same or a lower price, it is obvious that he or she will go for online shopping. However, in this case, it is important to also consider the issue of delivery, which should be settled by the marketers of online shopping. The functionality of the products/services online should be the same as the products/services that are sold in physical shops. Managers of online services should perhaps provide a virtual demonstration of the products/services that are sold in the online shopping platform. In addition, emotional values were also revealed as one of the predictors for online purchasing. There is, however, an important issue for managers to consider. Emotion is a human state that is very much in flux. Therefore, good precautions should be taken to successfully address this issue. Managers of businesses must ensure true and real enjoyment for consumers when they purchase online. The process should obviously be free of complexity and tediousness. In the context of Malaysian consumers, managers should offer online consumers different types of options and scope to purchase online. Consumers must not feel that it is a complex and boring procedure, which could discourage them from purchasing online. Therefore, managers should come up with a web interface and platform that gives consumers a sense of enjoyment and further curiosity to continue purchasing online. Managers of online businesses must consider these consumer values in order to attract Malaysian consumers to online purchasing.

Further research should not only be limited to testing in other countries or in a different consumer cohort. In addition to that, researchers could consider analysing the driving factors behind functional and emotional values. Also, research could be carried out among entrepreneurs that run e-commerce businesses to analyse the trend of online shopping. Furthermore, repurchasing intention could be considered to understand the consequences of functional and emotional values in online purchase intention. As e-commerce is increasing at great pace among all generations, all over the world, further understanding of these phenomena is increasingly warranted. 


\section{References}

Ajzen, I., \& Driver, B. L. (1992). Application of the theory of planned behavior to leisure choice. Journal of leisure research, 24(3), 207-224.

Ajzen, I., \& Fishbein, M. (1977). Attitudebehavior relations: A theoretical analysis and review of empirical research. Psychological bulletin, 84(5), 888-918.

Alden, D. L., He, Y., \& Chen, Q. (2010). Service recommendations and customer evaluations in the international marketplace: Cultural and situational contingencies. Journal of Business Research, 63(1), 38-44.

Amaro, S., \& Duarte, P. (2015). An integrative model of consumers' intentions to purchase travel online. Tourism Management, 46, 64-79.

Bolton, R. N., \& Drew, J. H. (1991). A multistage model of customers' assessments of service quality and value. Journal of consumer research, 375-384.

Bonsón Ponte, E., Carvajal-Trujillo, E., \& Escobar-Rodríguez, T. (2015). Influence of trust and perceived value on the intention to purchase travel online: Integrating the effects of assurance on trust antecedents. Tourism Management, 47, 286-302. doi:http://dx.doi.org/10.1016/j. tourman.2014.10.009

Brown, M., Pope, N., \& Voges, K. (2003). Buying or browsing? An exploration of shopping orientations and online purchase intention. European Journal of Marketing, 37(11/12), 16661684.

Chau, P. Y., \& Hu, P. J. H. (2001). Information technology acceptance by individual professionals: A model comparison approach*. Decision Sciences, 32(4), 699-719.

Childers, T. L., Carr, C. L., Peck, J., \& Carson, S. (2002). Hedonic and utilitarian motivations for online retail shopping behavior. Journal of retailing, 77(4), 511-535.
Chu, C.-W., \& Lu, H.-P. (2007). Factors influencing online music purchase intention in Taiwan: An empirical study based on the valueintention framework. Internet Research, 17(2), 139-155.

Cravens, D. W., Holland, C. W., Lamb, C. W., \& Moncrief, W. C. (1988). Marketing's role in product and service quality. Industrial Marketing Management, 17(4), 285-304.

Dai, B., Forsythe, S., \& Kwon, W.-S. (2014). The impact of online shopping experience on risk perceptions and online purchase intentions: Does product category matter? Journal of Electronic Commerce Research, 15(1), 13-24.

Davis, F. D. (1989). Perceived usefulness, perceived ease of use, and user acceptance of information technology. MIS quarterly, 319-340.

Duarte, P. A. O., \& Raposo, M. L. B. (2010). A PLS model to study brand preference: An application to the mobile phone market. In V. E. Vinzi, W. W. Chin, J. Henseler, \& H. Wang (Eds.). Handbook of Partial Least Squares (pp. 449-485). Berlin Heidelberg: Springer.

Ducoffe, R. H. (1996). Advertising value and advertising on the web. Journal of advertising research, 36(5), 21-35.

Engström, A., Styvén, M. E., Wallström, Å., \& Salehi-Sangari, E. (2015). Developing an attractive mobile service: A comparison of desired consumption values of three different services The Sustainable Global Marketplace, 454-456.

Everard, A., \& Galletta, D. F. (2005). How presentation flaws affect perceived site quality, trust, and intention to purchase from an online store. Journal of management information systems, 22(3), 56-95.

Fishbein, M., \& Ajzen, I. (1975). Belief, attitude, intention and behavior: An introduction to theory and research. Reading, MA: Addison-Wesley. 
Flanagin, A. J., Metzger, M. J., Pure, R., Markov, A., \& Hartsell, E. (2014). Mitigating risk in ecommerce transactions: Perceptions of information credibility and the role of user-generated ratings in product quality and purchase intention. Electronic Commerce Research, 14(1), 1-23.

Fornell, C., \& Larcker, D. F. (1981). Evaluating structural equation models with unobservable variables and measurement error. Journal of Marketing Research, 18(1), 39-50.

Gefen, D., Karahanna, E., \& Straub, D. W. (2003). Trust and TAM in online shopping: An integrated model. MIS quarterly, 27(1), 51-90.

Gopi, M., \& Ramayah, T. (2007). Applicability of theory of planned behavior in predicting intention to trade online: Some evidence from a developing country. International Journal of Emerging Markets, 2(4), 348-360.

Hair, J. F., Black, W. C., Babin, B. J., \& Anderson, R. E. (2009). Multivariate Data Analysis. Upper Saddle, New Jersey: Pearson Prentice Hall.

Hair, J. F., Ringle, C. M., \& Sarstedt, M. (2011). PLS-SEM: Indeed a silver bullet. The Journal of Marketing Theory and Practice, 19(2), 139-152.

Hanson, W., \& Kalyanam, K. (2007). Principles of Internet marketing. Nashville: South-Western College Publishing.

Samuel, L. H. S., Balaji, M. S., \& Kok Wei, K. (2015). An Investigation of online shopping experience on trust and behavioral intentions. Journal of Internet Commerce, 14(2), 233-254. do i: $10.1080 / 15332861.2015 .1028250$

Hellier, P. K., Geursen, G. M., Carr, R. A., \& Rickard, J. A. (2003). Customer repurchase intention: A general structural equation model. European Journal of Marketing, 37(11/12), 17621800.

Hoffman, D. L., \& Novak, T. P. (1996). Marketing in hypermedia computer-mediated environments: Conceptual foundations. The Journal of Marketing, 50-68.

Hsin Chang, H., \& Wang, H.-W. (2011). The moderating effect of customer perceived value on online shopping behaviour. Online Information Review, 35(3), 333-359.

Hur, W.-M., Yoo, J.-J., \& Chung, T.-L. (2012). The consumption values and consumer innovativeness on convergence products. Industrial Management \& Data Systems, 112(5), 688-706.

Javed, M. K., Nazam, M., Ahmad, J., Nadeem, A. H., \& Qadeer, T. (2015). Role of Web in an Online Setting: Consumers perceived risk toward online purchase intention. Paper presented at the Proceedings of the Ninth International Conference on Management Science and Engineering Management.

Johnson, M. W., Christensen, C. M., \& Kagermann, H. (2008). Reinventing your business model. Harvard business review, 86(12), 57-68.

Kacen, J. J., Hess, J. D., \& Chiang, W.-y. K. (2013). Bricks or clicks? Consumer attitudes toward traditional stores and online stores. Global Economics and Management Review, 18(1), 12-21.

Kim, Y.-K. (2002). Consumer value: An application to mall and Internet shopping. International Journal of Retail \& Distribution Management, 30(12), 595-602.

Laroche, M., Habibi, M. R., Richard, M.-O., \& Sankaranarayanan, R. (2012). The effects of social media based brand communities on brand community markers, value creation practices, brand trust and brand loyalty. Computers in Human Behavior, 28(5), 1755-1767.

Lee, C. H., Eze, U. C., \& Ndubisi, N. O. (2011). Analyzing key determinants of online repurchase intentions. Asia Pacific Journal of Marketing and Logistics, 23(2), 200-221. 
Lee, C. K., Levy, D., Yap, F., \& Sheau, C. (2015). How does the theory of consumption values contribute to place identity and sustainable consumption? International Journal of Consumer Studies, 39, 597-607.

Lee, J.-S., Lee, C.-K., \& Choi, Y. (2010). Examining the role of emotional and functional values in festival evaluation. Journal of Travel Research, 19. https://doi.org/10.1177/0047287510385465.

Lee, Y., Kim, J., Lee, I., \& Kim, H. (2002). A Cross-Cultural study on the value structure of mobile internet usage: Comparison between Korea and Japan. J. Electron. Commerce Res., 3(4), 227-239.

Ling, K. C., Daud, D., bin, Piew, T. H., Keoy, K. H., \& Hassan, P. (2011). Perceived risk, perceived technology, online trust for the online purchase intention in Malaysia. International Journal of Business and Management, 6(6), 167-182.

Long, M. M., \& Schiffman, L. G. (2000). Consumption values and relationships: Segmenting the market for frequency programs. Journal of consumer marketing, 17(3), 214-232.

Mohd Suki, N., \& Mohd Suki, N. (2015). Consumption values and consumer environmental concern regarding green products. International Journal of Sustainable Development \& World Ecology, 22(3), 269-278.

Moon, J., Chadee, D., \& Tikoo, S. (2008). Culture, product type, and price influences on consumer purchase intention to buy personalized products online. Journal of Business Research, 61(1), 31-39.

Moore, D. J., \& Harris, W. D. (1996). Affect intensity and the consumer's attitude toward high impact emotional advertising appeals. Journal of advertising, 25(2), 37-50.

Ok-Kim, J., \& Jin, B. (2001). Korean consumers' patronage of discount stores: domestic vs multinational discount store shoppers' profiles. Journal of Consumer Marketing, 18(3), 236-255.

Overby, J. W., \& Lee, E.-J. (2006). The effects of utilitarian and hedonic online shopping value on consumer preference and intentions. Journal of Business Research, 59(10), 1160-1166.

Park, D.-H., Lee, J., \& Han, I. (2007). The effect of on-line consumer reviews on consumer purchasing intention: The moderating role of involvement. International Journal of Electronic Commerce, 11(4), 125-148.

Pavlou, P. A. (2003). Consumer acceptance of electronic commerce: Integrating trust and risk with the technology acceptance model. International journal of electronic commerce, 7(3), 101-134.

Pihlström, M., \& Brush, G. J. (2008). Comparing the perceived value of information and entertainment mobile services. Psychology \& Marketing, 25(8), 732-755.

Podsakoff, P. M., MacKenzie, S. B., Lee, J.-Y., \& Podsakoff, N. P. (2003). Common method biases in behavioral research: A critical review of the literature and recommended remedies. Journal of Applied Psychology, 88(5), 879.

Podsakoff, P. M., \& Organ, D. W. (1986). Selfreports in organizational research: Problems and prospects. Journal of management, 12(4), 531-544.

Pookulangara, S., \& Koesler, K. (2011). Cultural influence on consumers' usage of social networks and its' impact on online purchase intentions. Journal of Retailing and Consumer Services, 18(4), 348-354.

Pope, N. (1998). Consumption values, sponsorship awareness, brand and product use. Journal of product \& brand management, 7(2), 124-136.

Rahman, S. A., \& Das, D. K. (2005). The development of small and medium enterprises 
(SMEs) in Bangladesh. Stamford Journal of Business Studies, 1(1), 108-123.

Rahman, S. A., Taghizadeh, S. K., Ramayah, T., \& Ahmad, N. H. (2015). Service innovation management practices in the telecommunications industry: What does cross country analysis reveal? SpringerPlus, 4(1), 810.

Ramayah, T., \& Ignatius, J. (2005). Impact of perceived usefulness, perceived ease of use and perceived enjoyment on intention to shop online. ICFAI Journal of Systems Management (IJSM), 3(3), 36-51.

Ramayah, T., Rouibah, K., Gopi, M., \& Rangel, G. J. (2009). A decomposed theory of reasoned action to explain intention to use Internet stock trading among Malaysian investors. Computers in Human Behavior, 25(6), 1222-1230. doi:http:// dx.doi.org/10.1016/j.chb.2009.06.007

San Lim, Y., Omar, A., \& Thurasamy, R. (2015). Online purchase: A study of generation $\mathrm{Y}$ in Malaysia. International Journal of Business and Management, 10(6), 1-7.

San Martín, H., \& Herrero, Á. (2012). Influence of the user's psychological factors on the online purchase intention in rural tourism: Integrating innovativeness to the UTAUT framework. Tourism Management, 33(2), 341-350.

Schechter, L. (1984). A normative conception of value. Progressive Grocer, executive report, 2, 12-14.

Sheth, J. N., Newman, B. I., \& Gross, B. L. (1991). Why we buy what we buy: A theory of consumption values. Journal of Business Research, 22(2), 159-170.

Sin, S. S., Nor, K. M., \& Al-Agaga, A. M. (2012). Factors Affecting Malaysian young consumers' online purchase intention in social media websites. Procedia - Social and Behavioral Sciences, 4O(0), 326-333. doi:http://dx.doi.org/10.1016/j. sbspro.2012.03.195
Smith, J. B., \& Colgate, M. (2007). Customer value creation: A practical framework. Journal of marketing Theory and Practice, 15(1), 7-23.

Sweeney, J. C., \& Soutar, G. N. (2001). Consumer perceived value: The development of a multiple item scale. Journal of Retailing, 77(2), 203-220. doi:http://dx.doi.org/10.1016/S00224359(01)00041-0

Turel, O., Serenko, A., \& Bontis, N. (2010). User acceptance of hedonic digital artifacts: A theory of consumption values perspective. Information \& Management, 47(1), 53-59. doi:http://dx.doi. org/10.1016/j.im.2009.10.002

Van Birgelen, M., Jong, A., De, \& Ruyter, K., De, (2006). Multi-channel service retailing: The effects of channel performance satisfaction on behavioral intentions. Journal of Retailing, 82(4), 367-377.

Van der Heijden, H., Verhagen, T., \& Creemers, M. (2003). Understanding online purchase intentions: Contributions from technology and trust perspectives. European Journal of Information Systems, 12(1), 41-48.

Venkatesh, V., Morris, M. G., Davis, G. B., \& Davis, F. D. (2003). User acceptance of information technology: Toward a unified view. MIS quarterly, 27(3), 425-478.

Verma, V., Sharma, D., \& Sheth, J. (2015). Does relationship marketing matter in online retailing? A meta-analytic approach. Journal of the Academy of Marketing Science, 1-12.

Westbrook, R. A., \& Oliver, R. L. (1991). The dimensionality of consumption emotion patterns and consumer satisfaction. Journal of consumer research, 84-91.

Woodruff, R. B. (1997). Customer value: The next source for competitive advantage. Journal of the Academy of Marketing Science, 25(2), 139-153. 
Wu, L. (2013). The antecedents of customer satisfaction and its link to complaint intentions in online shopping: An integration of justice, technology, and trust. International Journal of Information Management, 33(1), 166-176.

Zeithaml, V. A. (1988). Consumer perceptions of price, quality, and value: A means-end model and synthesis of evidence. The Journal of marketing, 2-22.
Zellweger, T. M., \& Astrachan, J. H. (2008). On the emotional value of owning a firm. Family Business Review, 21(4), 347-363.

Zwass, V. (1998). Structure and macro-level impacts of electronic commerce: From technological infrastructure to electronic marketplaces. Columbus: Irwin/McGraw-Hill.

\section{About the Authors:}

1. Ramayah, T., Master of Business Administration, Universiti Sains Malaysia, Penang, Malaysia.

E-mail: ramayah@usm.my

ORCID

(iD0000-0002-7580-7058

2. Rahman, Syed Abidur, Assistant Professor, Sultan Qaboos University, Muscat, Oman.

E-mail: syedabid728@gmail.com

ORCID

(iD)0000-0002-7889-920X

3.Ng Ching Ling, Bachelor of Management, Universiti Sains Malaysia, Penang, Malaysia.

E-mail: ngchinglingusm@gmail.com

ORCID

(D)0000-0001-8086-1799

\section{Contribution of each author}

\begin{tabular}{|c|c|c|c|}
\hline Contribution & Ramayah, $\mathbf{T}$ & Rahman, Syed Abidur & Ng Ching Ling \\
\hline 1. Definition of research problem & $\sqrt{ }$ & & \\
\hline 2. Development of hypotheses or research questions (empirical studies) & $\sqrt{ }$ & & \\
\hline 3. Development of theoretical propositions (theoretical work) & & & $\sqrt{ }$ \\
\hline 4. Theoretical foundation/Literature review & $\sqrt{ }$ & $\sqrt{ }$ & \\
\hline 5. Definition of methodological procedures & & $\sqrt{ }$ & \\
\hline 6. Data collection & & & $\sqrt{ }$ \\
\hline 7. Statistical analysis & $\sqrt{ }$ & $\sqrt{ }$ & \\
\hline 8. Analysis and interpretation of data & $\sqrt{ }$ & $\sqrt{ }$ & \\
\hline 9. Critical revision of the manuscript & & & $\sqrt{ }$ \\
\hline 10. Manuscript writing & $\sqrt{ }$ & $\sqrt{ }$ & \\
\hline
\end{tabular}

